\title{
THE CANADIAN ENDANGERED SPECIES ACT — IMPORTANT LEGISLATION IN DANGER OF EXTINCTION?
}

ROY JOHN and CURT SCHROEDER, Nature Saskatchewan, 1860 Lorne St., Regina, SK. S4P 2 L7

As we go to press, the whole process of passing federal endangered species legislation is in jeopardy. The plan called for public input and Nature Saskatchewan was spearheading a three-pronged approach with the Saskatoon and $R e$ gina clubs. We had developed a three-part presentation to be given at a meeting of the Standing Committee of the Environment in Edmonton, one of several meetings to be held across the country. The meeting was cancelled and re-instated several times before finally being cancelled. Apparently the Bloc Québécois is trying to affect other legislation and is using this Bill in its tactics. Our current (end of November) understanding is the government will try to push the Act through second reading and hold the meetings in late December 1996, January or February 1997.

On a more positive note, the Province has begun a process to add legislation to provide protection on provincial lands. Nature Saskatchewan is cooperating with SERM in this process, which should be complete by the summer of 1997.

The federal government's act to protect Canada's endangered wildlife was tabled in the House of Commons on 31 October 1996. What does this mean for Saskatchewan, the other prairie provinces and the rest of Canada?
The problem of species decline and threat of extinction was recognized years ago. The United States has had legislation since 1973, and, while it is not perfect, it has made a difference. Despite early fears the legislation has had little impact on development; of the "consultations" required by the U.S. Act, only about $2 \%$ have resulted in an impact on the development proposal. Mainly due to underfunding of recovery programs, the record for protecting the species is less impressive; 26 have become extinct. Four provinces, Manitoba, Ontario, Quebec and New Brunswick, have also passed legislation to protect endangered species, but again lack of action has limited their usefulness. Sheila Copps, as Environment Minister, in 1995 began the process to introduce a federal Endangered Species Act and the current minister, Sergio Marchi, has continued the work. During this period, naturalists have lobbied intensively, spearheaded by the Canadian Endangered Species Coalition (Canadian Nature Federation, Canadian Parks and Wilderness Society, Sierra Club, Sierra Legal Defence Fund and the Union Québécois pour la Conservation de la Faune). Their efforts have largely gone unheralded by the public and unnoticed by the media.

The basis for the new Act is a list prepared by a voluntary group of respected scientists called the 
Committee on the Status of Endangered Wildlife In Canada (COSEWIC). The 1996 version of this list contains 264 Canadian species at risk, $19 \%$ mammals, $19 \%$ birds, $22 \%$ fish, $33 \%$ plants, and some other animals. Of this number, 57 species are considered endangered (that is, threatened with immediate extinction or extirpation). Nine species, including Great Auk, Passenger Pigeon and Labrador Duck are already extinct; lost forever. Of the 264, 29 species, including eight endangered, occur in Saskatchewan; 35, including 6 endangered in Manitoba; and 31, including six endangered, in Alberta.

Saskatchewan's endangered species include the Whooping Crane, with a current wild population of about 170 birds. The Eskimo Curlew, once numbered in the countless millions, is so rare that it was thought extinct. There was a recent possible sighting of this bird in Manitoba, reported in Blue Jay. The Burrowing Owl is now down to between 1000 and 1500 pairs in Canada. A recovery program, spearheaded by Nature Saskatchewan for the last eight years, that includes voluntary cooperation by landowners (Operation Burrowing Owl) to leave their nesting habitat intact, was started in 1987 , but these birds are still losing ground. The Peregrine Falcon was decimated by the now banned pesticide, DDT. One pair from a captive breeding program now nests in downtown Saskatoon. The Piping Plover has suffered from changes in habitat and human disturbance. Fifty percent of the Canadian Piping Plover population nests in Saskatchewan and this year's census found an encouraging 1340 birds, up about $15 \%$ in five years. However, Margaret Skeel reports that the overall population is up by only $2 \%$ and believes that the Saskatchewan increase includes many immigrants. The Mountain Plover had one nest in 1987, and maybe one in 1991 in Saskatchewan. There is a recovery plan for Alberta; but not for Saskatchewan. There have only been seven recent records of Sage Thrasher. Our single endangered plant, the Slender Mouse-ear Cress, has no protection at all and now may be reduced to a few plants. The Bigmouth Buffalo fish, which lives in the Lake of the Prairies, is listed as vulnerable. Its habitat may be at risk, depending on the outcome of the current Upper Assiniboine River Basin Study. The Swift Fox was once eliminated (extirpated) from Canada by shooting, poisoning and habitat loss. A reintroduction of over 750 captive and wild-born Swift Foxes into Alberta and Saskatchewan has recently begun to show signs of success.

So what will the new Canadian Endangered Species Act (CESA) do for us? Sadly not nearly as much as we wanted. The good news is that Canada is finally passing a federal law to protect its species at risk. The Act includes most of the recommendations of the federal Endangered Species Task Force, although it falls short in some critical areas. Where it applies, it prohibits anyone from killing or harming a species at risk, or damaging its residence (we are not sure how to interpret "residence"). Extirpated species are not afforded this same protection, a major flaw in the Bill. Recovery plans are required within one year of listing for endangered species, and within two years of listing for threatened and extirpated species. Management plans for vulnerable species and their critical habitats are required within three years of listing. The most unwelcome aspect is that the minister and the cabinet have unbridled discretion about listing of endangered species. 
COSEWIC will advise on listing, but cabinet will make the decisions.

Only about $40 \%$ of Canada's species at risk (aquatic species, most migratory birds, and species on federal lands) are protected from direct harassment by this Act. Even less, about $30 \%$ would be eligible for habitat protection under the Act. This is because habitat can be protected for aquatic species and those that live on federal lands, but not migratory birds or international transboundary species. Another drawback is that although habitat protection measures must be addressed in a recovery plan, these plans have no legal force. The government will decide what, if any, measures in a recovery plan will be implemented, including habitat protection. Also, if the Act is extended to cover species that cross national borders a further $20 \%$ of the species at risk would receive some coverage.

The Bill does not require advance review of projects that will affect species at risk, except where such review is already required under other federal legislation. The new legislation would be much stronger and more useful if it required an advance review of all projects identified as having the potential to affect an endangered species. The folly of not having an advanced review places the proponent at risk of contravening the Act and being subject to stiff penalties. It seems prudent to avoid that risk by having an advanced review.

A number of our species face persistent threats to survival and continue to decline, some more dramatically than others. Where COSEWIC finds that a species is in imminent danger, the minister may provide emergency protection, but is not required to do so. We cannot afford to lose a species and we cannot wait while the bureaucratic process unfolds. When a species is faced with extinction or extirpation, then we Canadians should expect immediate action from the minister. Exemption permits may be granted where harm to a species is minimized. But the Act allows a broad blanket exemption for any activity taken for the protection of national security, health and safety, including health and safety of plants or animals. What this means is not clear. The Act does allow a citizen to bring a private action into court when the government has failed to enforce the law. However, the citizen must wait for the government to complete an investigation of the matter first, even if there is an immediate threat to a species' survival.

Overall, the Bill authorizes the federal government to take the steps needed to protect Canada's species at risk (e.g., listing, habitat protection), but does not require that it do so.

COSEWIC lists 27 species at risk that are part of Saskatchewan's wildlife. Of these 27 only two (possibly three, if the Smooth Goosefoot occurs in the Dundurn Military camp) will gain any protection from the proposed legislation as it is currently written. About $80 \%$ of the Saskatchewan Black-tailed Prairie Dogs inhabit Grasslands National Park while the Wolverine occurs in Prince Albert National Park. The remaining species live outside lands under federal jurisdiction. The Bill also applies to federal crown corporations, including the PFRA and FCC. If these agencies, which own a substantial amount of land in the prairie zone, do not seek exemption from this Act, then they will contribute to species conservation. These we see as major weaknesses of the new Act 


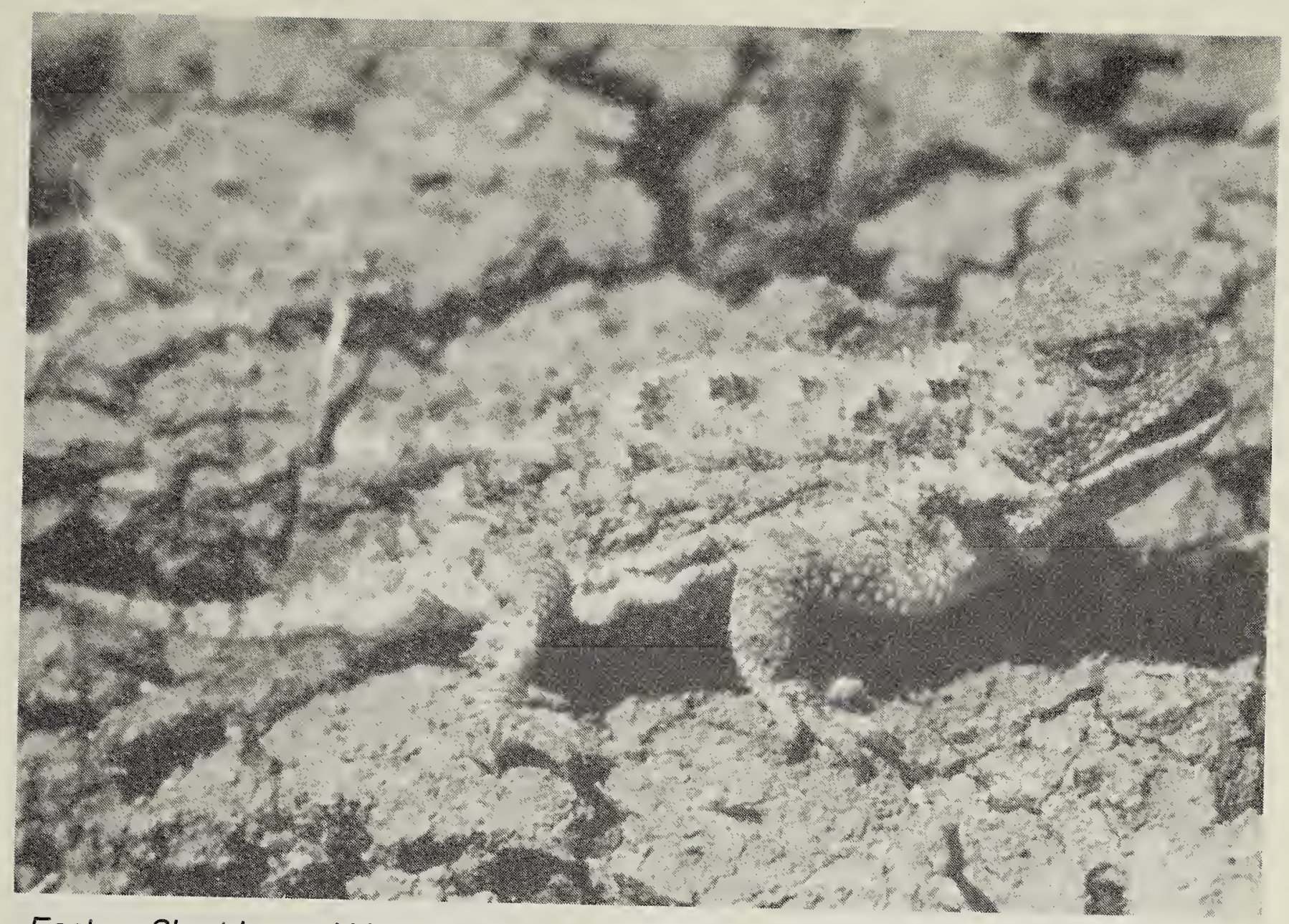

Eastern Short-horned Lizard - one of Saskatchewan's species at risk Wayne Lynch

and areas that must receive immediate attention. We recognize that under our constitution there are severe limitations imposed on the federa government to take unilateral action We understand that wildlife has been interpreted by the courts as a "natural resource" and in the control of the provinces. Endangered species, in our view, transcend the narrow legal and political interpretations we use for jurisdictional issues and reach a level of national importance. The problem is best exemplified by the plight of the Whooping Crane. Although this extremely rare bird has enjoyed the benefits of more than 50 years of conservation effort, it still numbers only about 170 individuals. Because Whoopers breed mostly in Wood Buffalo National Park on federal land, their nesting area is largely protected. But about two-thirds of these birds migrate and stage in and around Saskatoon on private farmland. This is as critical a time as breeding, for the birds need to build up their reserves for the flight to
Texas. While they are protected from direct threat by the terms of the Migratory Birds Convention Act (MBCA), they do not have full protection as endangered species. Projects and actions that could disrupt their passage south could not be stopped by the MBCA. Of the remaining 25 species not covered by CESA in Saskatchewan, nine, including Whooping Crane, receive some protection from the MBCA and four have blanket coverage by the Fisheries Act. Currently, then, there is some measure of federal protection for $48 \%$ of the species at risk in Saskatchewan. The CESA would extend this to $55 \%$. The Bill does not extend protection to all migratory species, leaving a large taxonomic group known as raptors (birds of prey) out of the Act. In Saskatchewan this would mean that the Burrowing Owl and Ferruginous Hawks would not receive full protection under the Act. While our analysis was done for species found in Saskatchewan, it appears that these numbers are typical 
for the rest of the country. The Act has the potential to give a significant increase in protection to those that need it most, but, as written, it falls short of the needed coverage. We need a stronger CESA.

COSEWIC has already established a credible reputation nationally and internationally as a scientifically defensible body of recognized experts. It is to the federal government's credit that it has recognized the contribution made by the COSEWIC and will formalize its existence in CESA. There is an unnecessarily restrictive three-year limit on the term of office in COSEWIC. While having some turnover in the committee membership is essential, turnover for its own sake is not worthwhile. Also, the required regional representation is a political not a scientific criterion. The aims of CESA should be to protect wildlife not to provide political credits for committee appointments. Even nonCanadians should be eligible for membership.
The species at risk not fully covered by the discussion above are plants. In Saskatchewan we have five species of plants in need of protection, some unique to this province. The one endangered plant, Slender Mouse-ear Cress, mostly grows on farmland near the town of Lucky Lake. Most of the animal species are in difficulty because of habitat destruction. With plants this is doubly true, as they are bound to a fixed locality by their dependence on specific growing conditions. Lack of habitat protection, one key weakness with this bill, is particularly evident when considering this province's plants.

These are some of the comments generated about CESA so far. Nature Saskatchewan and its affiliates will be continuing their work to improve the value of this bill for those that need it most: our endangered species.

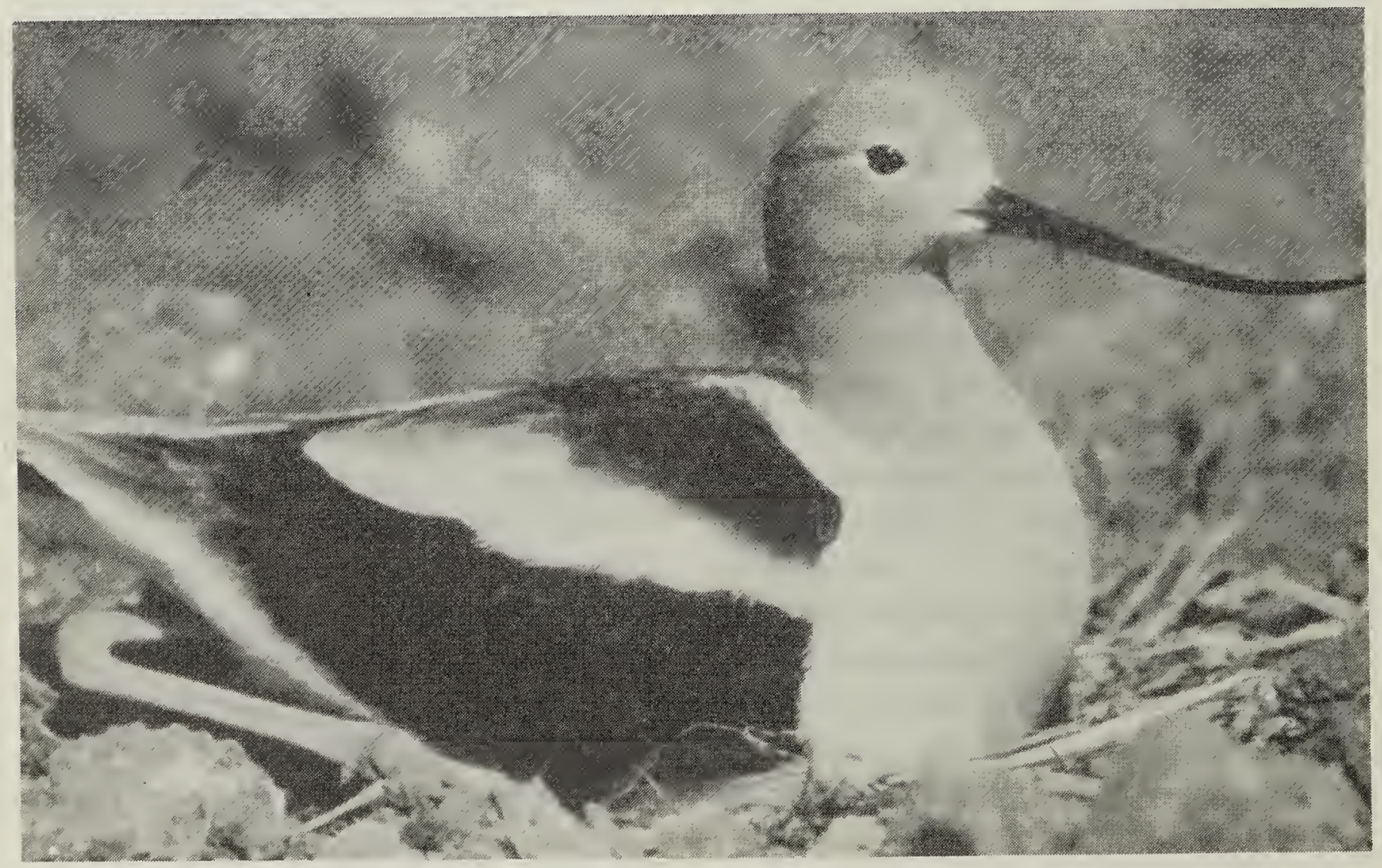

